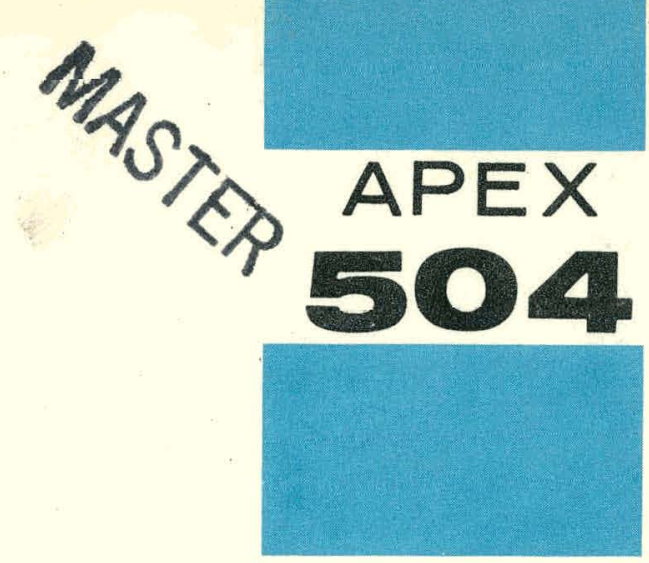

\title{
COMPARISON OF BULK SHIELDING REACTOR CENTERLINE MEASUREMENTS IN WATER WITH PREDICTIONS
}

\author{
A.W. CASPER
}

GENERAL ELECTRIC ATOMIC PRODUCTS DIVISION 


\section{DISCLAIMER}

This report was prepared as an account of work sponsored by an agency of the United States Government. Neither the United States Government nor any agency Thereof, nor any of their employees, makes any warranty, express or implied, or assumes any legal liability or responsibility for the accuracy, completeness, or usefulness of any information, apparatus, product, or process disclosed, or represents that its use would not infringe privately owned rights. Reference herein to any specific commercial product, process, or service by trade name, trademark, manufacturer, or otherwise does not necessarily constitute or imply its endorsement, recommendation, or favoring by the United States Government or any agency thereof. The views and opinions of authors expressed herein do not necessarily state or reflect those of the United States Government or any agency thereof. 


\section{DISCLAIMER}

Portions of this document may be illegible in electronic image products. Images are produced from the best available original document. 


\section{LEGAL NOTICE}

This report was prepared as an account of Government sponsored work. Neither the United States, nor the Commission, nor any person acting on behalf of the Commission:

A. Makes any warranty or representation, expressed or implied, with respect to the accuracy, completeness, or usefulness of the information contained in this report, or that the use of any information, apparatus, method, or process disclosed in this report may not infringe privately owned rights; or

B. Assumes any liabilities with respect to the use of, or for damages resulting from the use of any information, apparatus, method, or process disclosed in this report.

As used in the above, "person acting on behalf of the Commission" includes any employee or contractor of the Commission, or employee of such contractor, to the extent that such employee or contractor of the Commission, or employee of such contractor prepares, disseminates, or provides access to, any information pursuant to his employment or contract with the Commission, or his employment with such contractor.

Printed in USA, Price $\$ 1.00$. Available from the Office of Teghnical Services

U.S. Departmert of Commorce Washington 25, D.C.

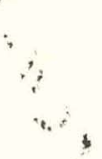




\title{
COMPARISON OF BULK SHIELDING REACTOR CENTERLINE MEASUREMENTS IN WATER WITH PREDICTIONS
}

\author{
A. W. Casper \\ Nuelear Development Laboratories Sub-Section \\ Hovember 1958 \\ United Stotes Air Force \\ United Stotes Atomic Energy Commission \\ Contract Mo. AF 33(600)-38062 \\ Contract No. AT (11.1)-171
}

\section{GENERAL SOECTRIC \\ ATOMIC PRODUCTS DIVISION AIRCRAFT NUCLEAR PROPULSION DEPARTMENT \\ Cincinnati 15, Ohio}

Published by

Technical Publications Sub-Section

July 1959 


\begin{abstract}
Measurements of fast neutron and gamma ray dose rates in water along the centerline of the Bulk Shielding Reactor (BSR) are compared with predictions made by use of three available computer programs. It is found that the predictions are very dependent on the assumptions made conceming power distribution and that the more accurate descriptions of the source lead to predictions that agree with measurements to within 20 percent throughout thickness ranges as great as 100 centimeters of water.
\end{abstract}




\section{Comparison of Bulk Shielding Reactor Centerline Measurements in Water With Predictions}

\section{INTRODUCTION}

Measurements of fast neutron and gamma ray dose rates ${ }^{1}$ are compared with the predictions of point-kernel computation programs $04-1,04-2$, and $14-0.6$ These three programs provide a variety of source descriptions. The source description used in each program is given. Buildup, cross sections, and conversion factors which were employed are also listed. In the gamma dose predictions the secondary gamma dose rate from water is added to the core gamma dose rate.

The gamma-ray point-kernel method used consists, briefly, of combining source-point to receiverpoint attenuation with Nuclear Development Corporation of America (NDA) build-up factors summed over energy and source volume. These programs are based on the assumption that the gamma ray attenuation between a source point and a receiver point can be described by a function of the form

$$
\Psi\left(\mathrm{E}_{\mathrm{j}}\right)=\mathrm{B}\left(\mathrm{X}_{\mathrm{j}}, \mathrm{E}_{\mathrm{j}}\right) \cdot \epsilon^{-\mathrm{X}_{\mathrm{j}}}
$$

where $X_{j}=\Sigma\left(\mu_{j} t\right)$. The function $\Psi\left(E_{j}\right)$ is the attenuation of gamma rays of the $j$-th energy group, and $\Sigma\left(\mu_{j} t\right)$ represents the sum of the relaxation lengths in the path.

The total gamma ray energy flux at a given point is then computed for cylindrical source volumes as

$$
\Phi_{y}=\sum_{j=1}^{\mathrm{J}} \frac{\mathrm{CB}_{j}}{4 \pi} \int \mathrm{P}(\mathrm{Z}) \mathrm{dZ} \int \mathrm{r} \mathrm{p}(\mathrm{r}) \mathrm{dr} \int \frac{\Psi\left(\mathrm{E}_{\mathrm{j}}\right)}{\rho^{2}} \mathrm{~d} \phi
$$

where the integration is carried out over the entire volume of the core. (For noncylindrical sources the integration is also carried out over the entire core volume, but the form of the volume integral is modified appropriately.) The summation indicated is over energy groups; $B_{j}$ is the source strength for the $j$-th energy group in Mev/ $\mathrm{cm}^{3}$-watt at the point of maximum power in the core; $\mathrm{p}(Z)$ and $\mathrm{p}(\mathrm{r})$ are functions describing the power distribution in the core; $\rho$ is the distance between source and detector points; and $\Psi$ has the form given in equation (1).

The gamma dose rate measurements ${ }^{1}$ were expressed in ergs $/ g_{\text {graphite }}$-hr-watt. The conversion factors used to convert the point-kernel dimensions to those employed in the measurements are listed on page 24 . They were obtained by multiplying the mass energy absorption coefficients for graphite 5 by the factor $5.76 \times 10^{-3} \frac{\mathrm{ergs} / \mathrm{hr}}{\mathrm{Mev} / \mathrm{sec}}$. 


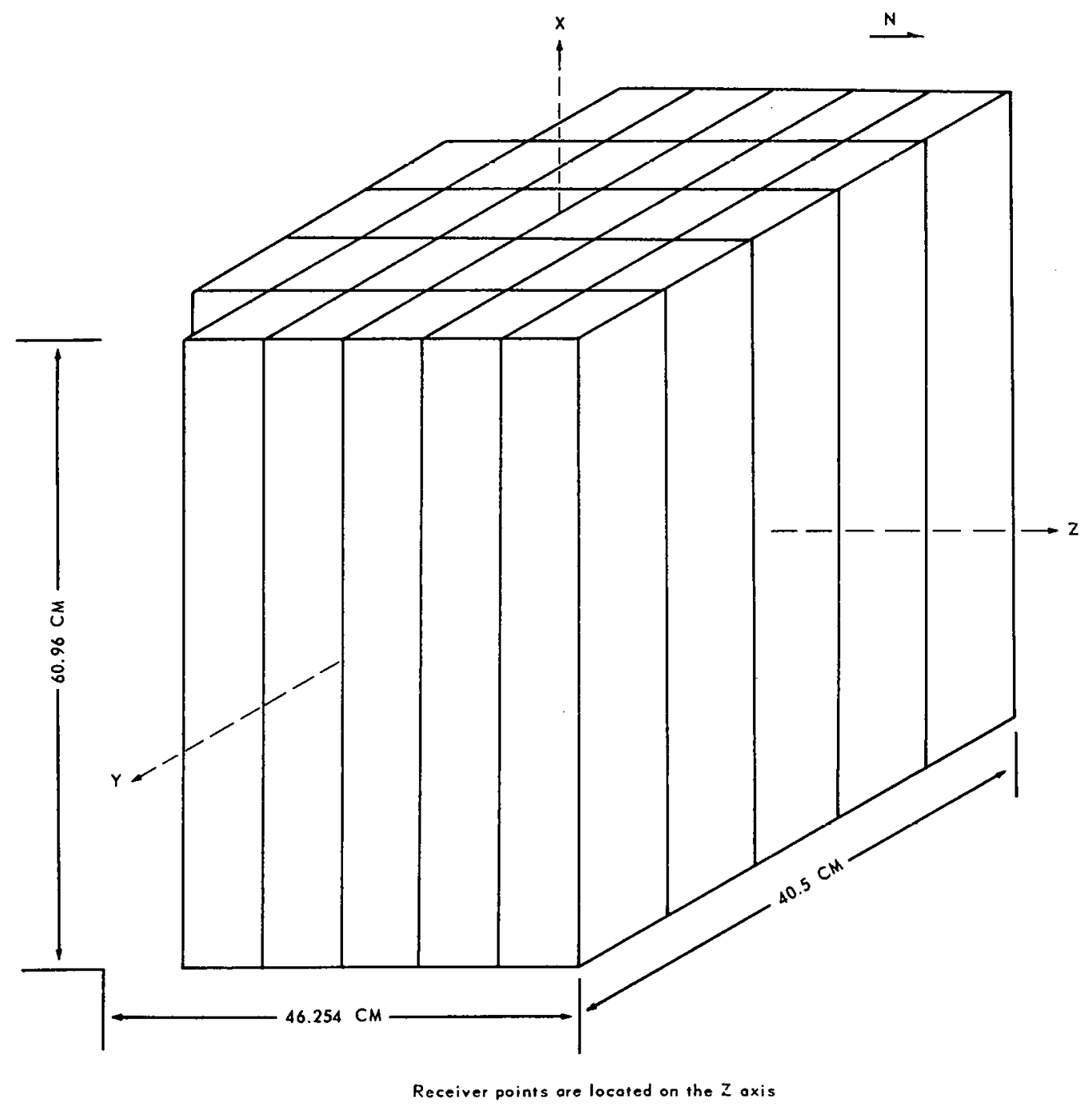

Fig. 1 - Schematic representation of the Bulk Shielding Reactor, loading number 33 
The source-point to receiver-point material attenuation function used for fast neutrons in these programs is

$\Psi_{\mathrm{n}}(\theta, \rho)=7.29 \times 10^{9}\left(\rho \sum_{\mathrm{m}=1}^{\mathrm{L}} \eta_{\mathrm{m}} \theta_{\mathrm{m}}\right)^{0.29} \exp \left\{-0.83\left(\rho \sum_{\mathrm{m}=1}^{\mathrm{L}} \eta_{\mathrm{m}} \theta_{\mathrm{m}}\right)^{0.58}\right\} \operatorname{cxp}\left(-\rho \sum_{\mathrm{m}=1}^{\mathrm{M}} \theta_{\mathrm{m}} \Sigma_{\mathrm{m}}\right)$.

This function yields dose rates in units of mrep/hr-watt. $\eta_{\mathrm{m}}$ is the ratio of the hydrogen atom density in material $\mathrm{m}$ to that in $70^{\circ} \mathrm{F}$ water. $\mathrm{L}$ refers to the hydrogenous materials among the $\mathrm{M}$ materials. The distance from the source point to the receiver point is designated by $\rho ; \theta_{m}$ is the volume fraction of material $\mathrm{m}$; and $\Sigma_{\mathrm{m}}$ is the fast neutron removal cross section for the nonhydrogenous portion of material $\mathrm{m}$.

The fast neutron dose rate from an entire source region is given by

$$
D_{n}=\int_{\substack{\text { source } \\ \text { region }}} \frac{S\left(\vec{r}_{s}\right) \Psi_{n}(\theta, \rho)}{4 \pi \rho^{2}} d V_{s} .
$$

The manner of integration depends on the source description. The geometric attenuation is given by the function $1 / 4 \pi \rho^{2}$. The source strength at each point within the source volume is given by $S\left(\vec{r}_{S}\right)$. Equation (3) describes the function $\Psi_{\mathbf{n}}(\theta, \rho)$.

The measured fast neutron dose rates were expressed in ergs/ $/ g_{\text {tissue }}$-hr-watt. The measured values were converted to the dimensions used in the point-kernel programs by the conversion factor,

$$
1 \mathrm{rep} / \mathrm{hr} \text {-watt }=93 \mathrm{ergs} / \mathrm{g}_{\text {tissue }}-\mathrm{hr}-\text { watt. }
$$

\section{SOURCE DESCRIPTIONS}

Available information ${ }^{2}$ about power distribution in the BSR is in the form of histograms for the $Y$ and $Z$ coordinates. The variation in power in the $X$ direction is described as continuous. The reactor and the fuel elements are treated as rectangular in shape as shown in Figure 1.

Program 04- 1 permits a rectangular core description. The missing fuel elements in the rectangular array are described as having zero power. Option 1 in the program was used in an early attempt to describe the power distribution as a continuous function in all three variables. The use of this option led to a difference of 100 percent or greater between measured and predicted values of gamma dose. Option 2 in program 04-1 makes it possible to use the given BSR information in an accurate description of the power distribution. In this option the reactor is described in the input data by means of a table of values of power density at 504 points in one-fourth of the core. When this option was used, the difference between measured and predicted values of gamma dose was less than 40 percent of the measured values for receiver points at distances greater than 20 centimeters from the reactor. It is clear that small differences in source power distribution lead to large differences in gamma dose rate in this problem.

The power density values used in option 2 of program 04-1 are listed in Table 1. Power density values associated with the 504 points used in describing one-fourth of the reactor core are given. The dimensions of the core are $X=-30.48$ to 30.48 centimeters, $Y=-20.25$ to 20.25 centimeters, and $Z=-23.127$ to 23.127 centimeters. Dose rates were calculated at receiver points in the water between $Z=29.777$ centimeters and $Z=150$ centimeters.

In program 04-2, which permits cylindrical source descriptions only, the rectangular source is replaced with an equivalent cylindrical source. The cross section of the cylinder that is considered 


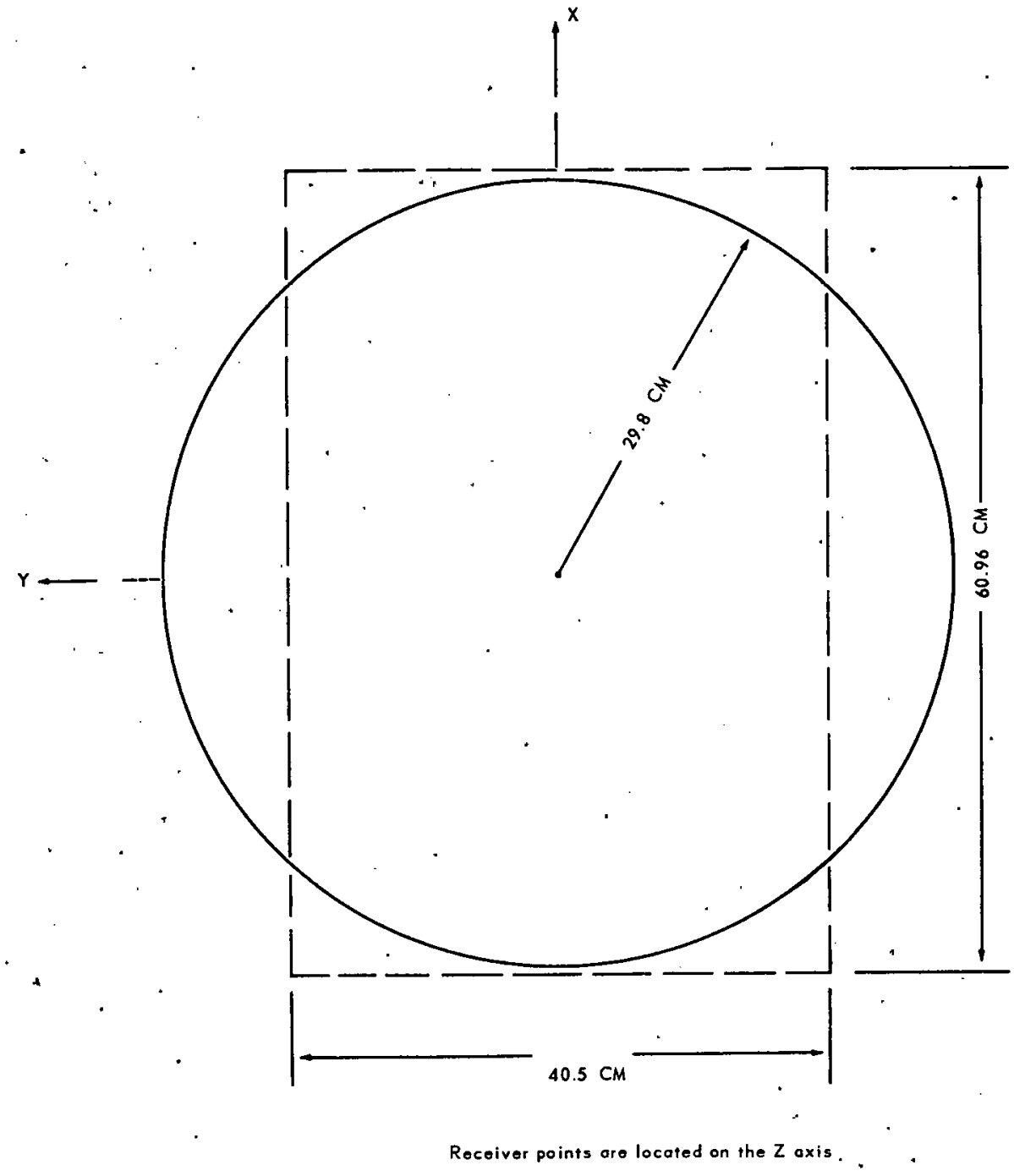

Fig. 2-Comparison of rectongular-core and cylindrical-core cross sections 
to be equivalent to the rectangular cross section of the core is shown in Figure 2. The boundaries of the equivalent cylindrical source are $Z=-20.003$ to 18.097 centimeters and $r=0$ to 29.8 centimeters. This description makes the volume of the cylinder equal to the volume of the active core. The distribution of power in the equivalent cylindrical source is described with a radial and axial source function. The radial source function used in the program is $P_{5}=1 \cdot \cos 0.0374 \mathrm{r}$. The axial source function used in the program is $P_{Z}=1.437 \times 10^{-5} \cos 0.03436(Z+4.763)$.

The source distribution is described in program 14-0 as 28 lines. The geometry is indicated in Figure 3. The lines are parallel and located at the center of each fuel element. Points where the lines intersect the $X-Y$ plane are located by the polar coordinates, $R$ and $\phi$. The power is assumed to vary along the $Z$ coordinate, and three ranges are used. The lines are divided into six types with a different power description being used for each type. The location of the lines and the power distribution assumed are given in Table 2.

The energy distribution of the gamma source intensity is given in Table 3.

BUILDUP, CROSS SECTIONS, AND CONVERSION FACTORS

The gamma dose buildup, the gamma ray linear absorption cross sections, and the flux-to-dose conversion factors employed in the programs are listed in Tables 4,5 , and 6 , respectively. The 04-2 programs used 10 energy groups in the gamma dose predictions. Initial poor results with program 04-1 led to the use of 13 energy groups, but only a small improvement was noted when this change was made. The 13 energy groups are used in the program 04-1 and program 14-0 predictions.

The value 0.0308 per centimeter is used for the neutron removal cross section for oxygen. The uranium and aluminum neutron removal cross sections used are 0.17 per centimeter and 0.079 per centimeter, respectively.

SECONDARY GAMMA RAYS FROM THERMAL NEUTRONS

The source of secondary gamma rays considered here is the $2.23-\mathrm{Mev}$ gamma ray from hydrogen. The thermal neutron cross section used for the $(n, y)$ reaction is 0.33 barns. Measured values of axial thermal neutron flux are fitted by exponential functions and used as source terms. Measured values from a similar configuration are used to determine radial source functions. The source distribution used is given in Table 7. Water buildup is used. The source was a cylinder 400 centimeters long and 60.96 centimeters in radius. The secondary gamma dose is shown in Figure 4.

\section{GAMMA RAY AND NEUTRON DOSE PREDICTIONS}

Neurron dose rates given by programs $04-2,04-1$, and 14-0 are compared with measured values in Figures 5,6 , and 7 , respectively. Differences between measured values and predictions near the reactor are noted. The large difference is partly due to widely spaced source points and source points on the surface of the reactor. Program 14-0 has no source points on the reactor surface, and neutron dose rates close to the reactor compare more favorably with measured values in this case.

Gamma dose rates given by programs $04-2,04-1$, and 14-0 are compared with measured values in Figures 8,9 , and 10 , respectively. Secondary gamma rays from thermal neutrons are included in the gamma dose predictions. The predicted values agree better with measured values as distances between the reactor and the receiver points increase. This fact is quite clear in Figures 5 and 6 where the source descriptions are better than the description in the program 04-2 problem.

Better agreement between measured and predicted values should be possible by an alteration in the source description. Increasing the number of source points would be one way of improving the source description. How ever, the value of working for such close agreement should be carefully weighed against cost, inasmuch as the experimental uncertainties in the measurements are as great at 20 percent. 1 


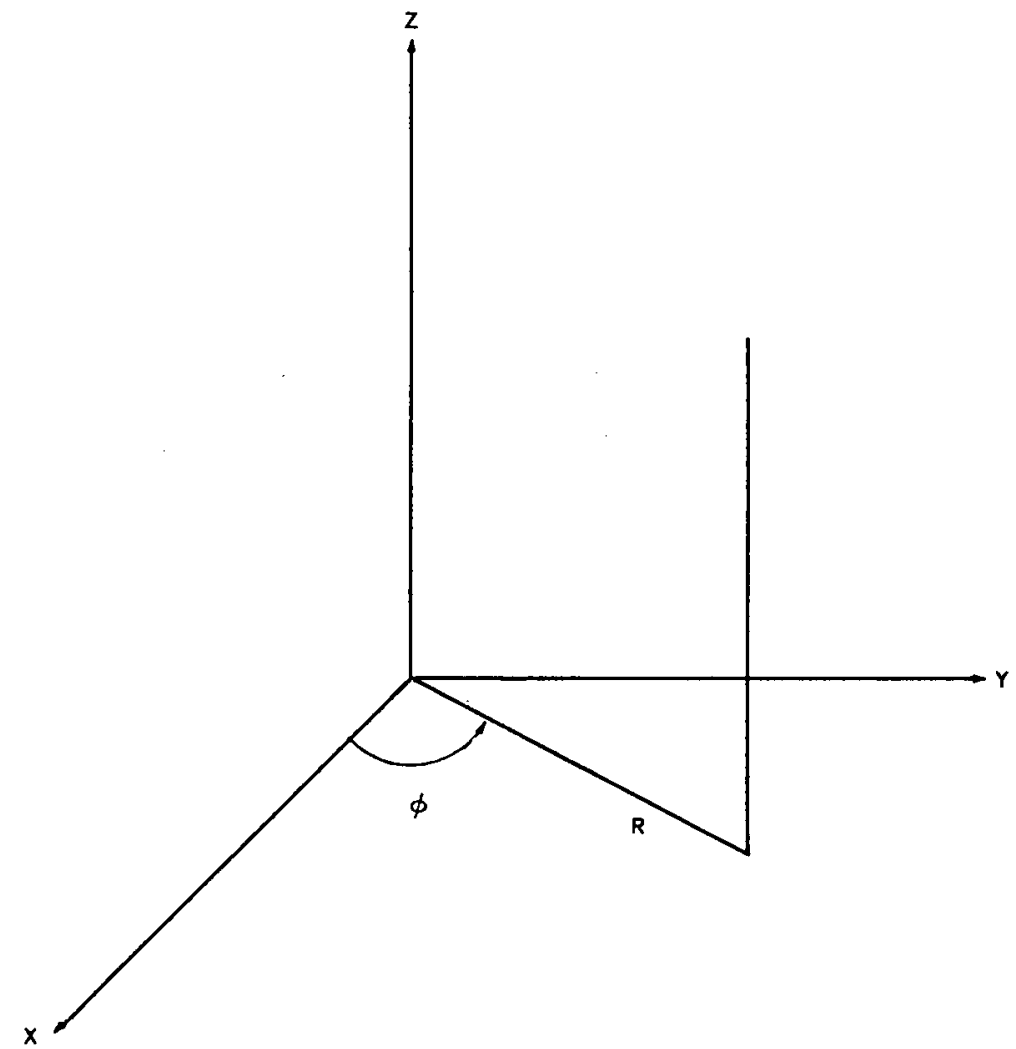

Receiver points are located on the $Y$ axis

Fig. 3-Coordinate system used for locating the lines in progrom 14.0 source description 


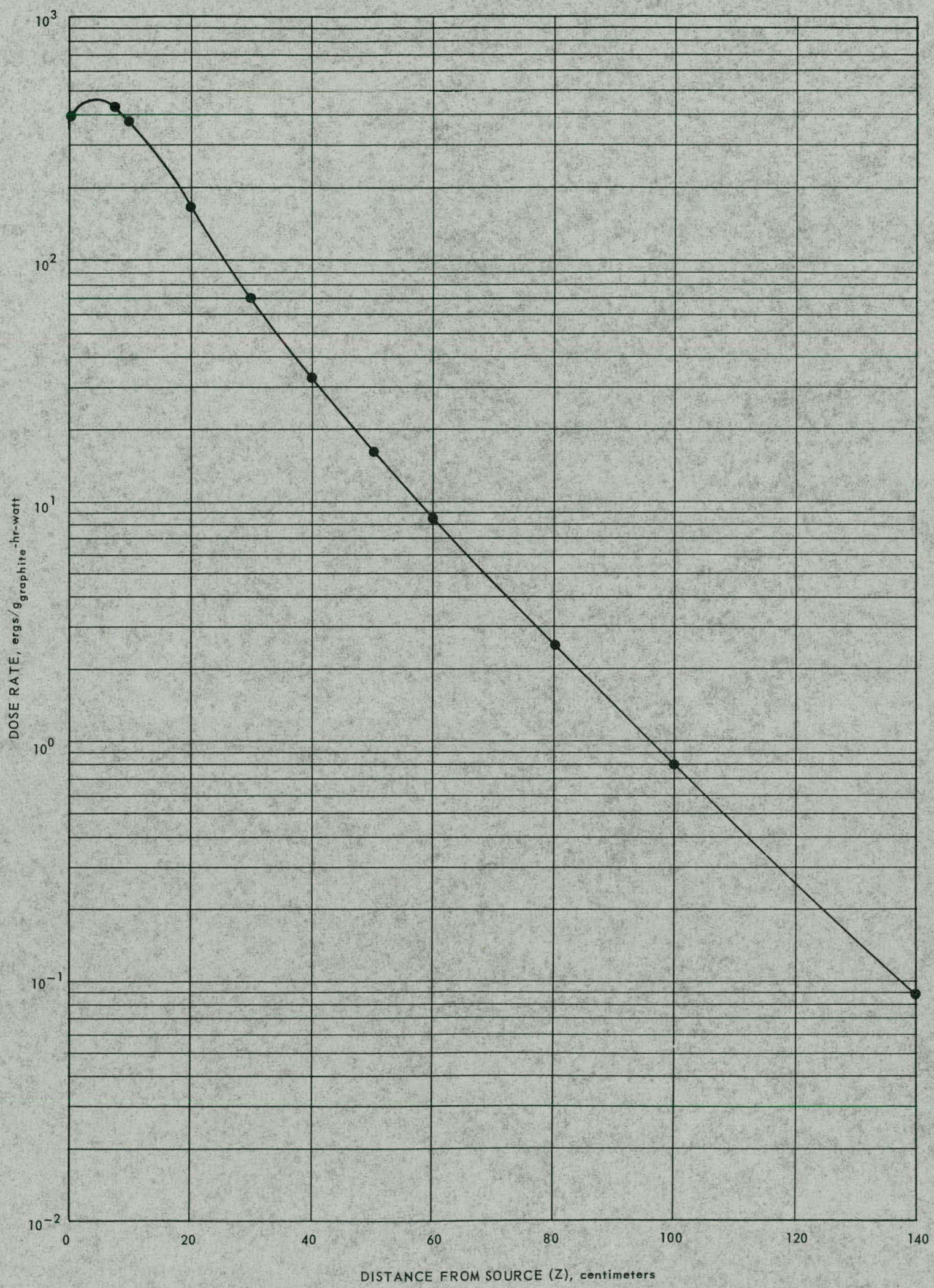

Fiq. 4-Bulk Shielding Reactor centerline secondary gamma dose rate in water, louding number 33 


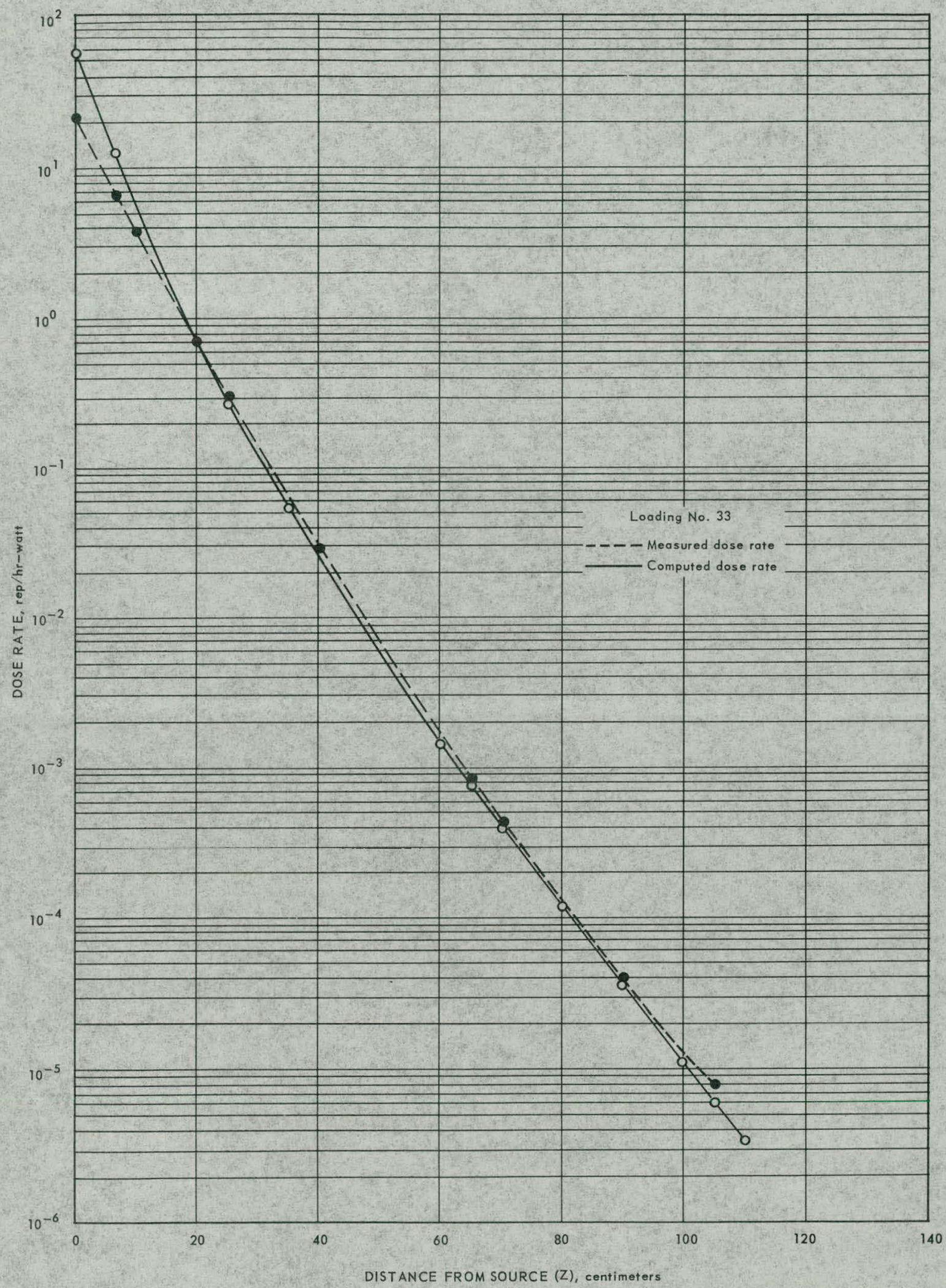

Fiy. 5 - Cumpurisuil of meusured und cumputed program 04-2 BSR centerlinc neutron dose rates in water 


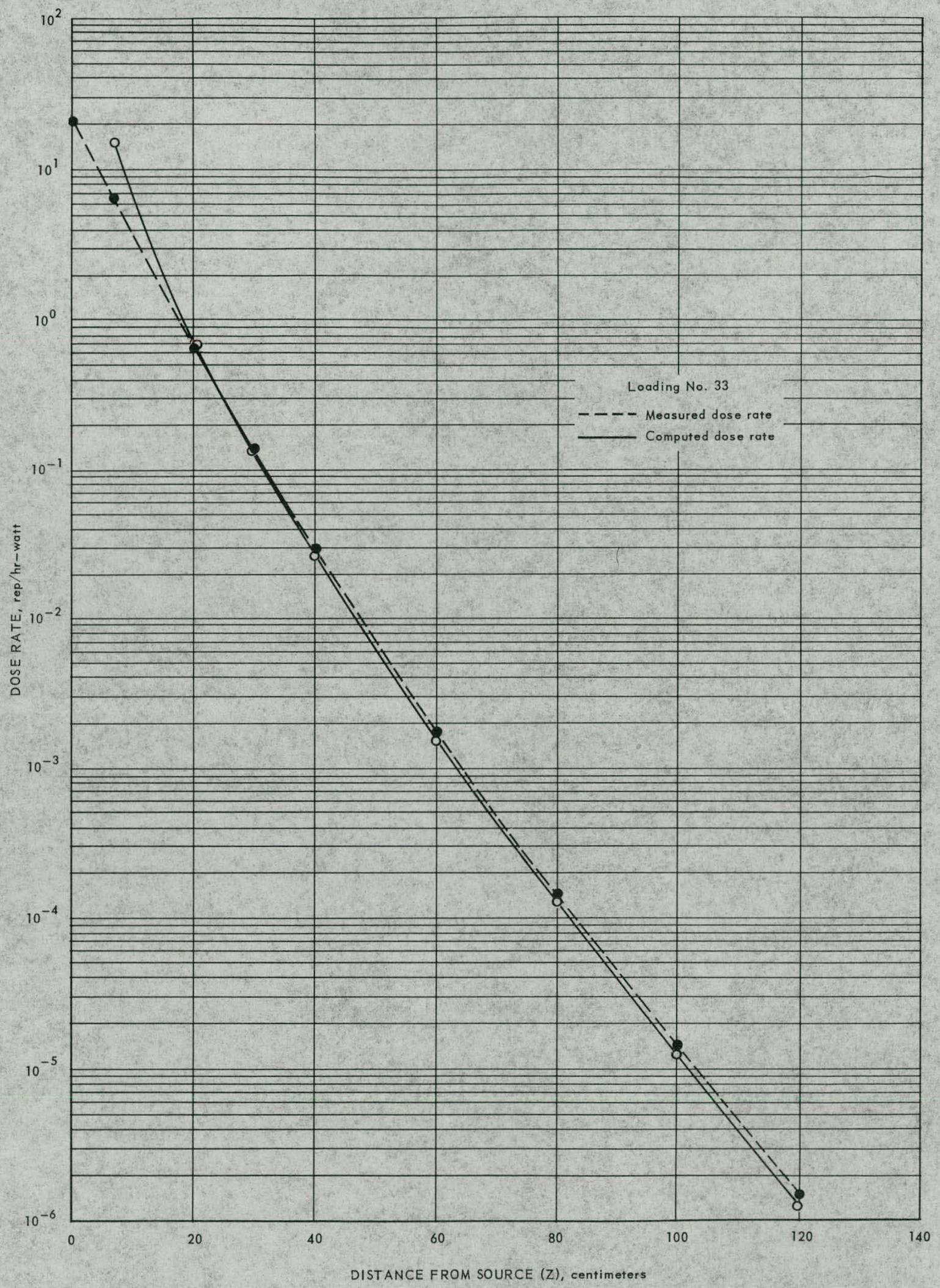

Fiq. 6-Comparis on of measured and computed program 04-1 BSR centerline neutron dose rates in water 


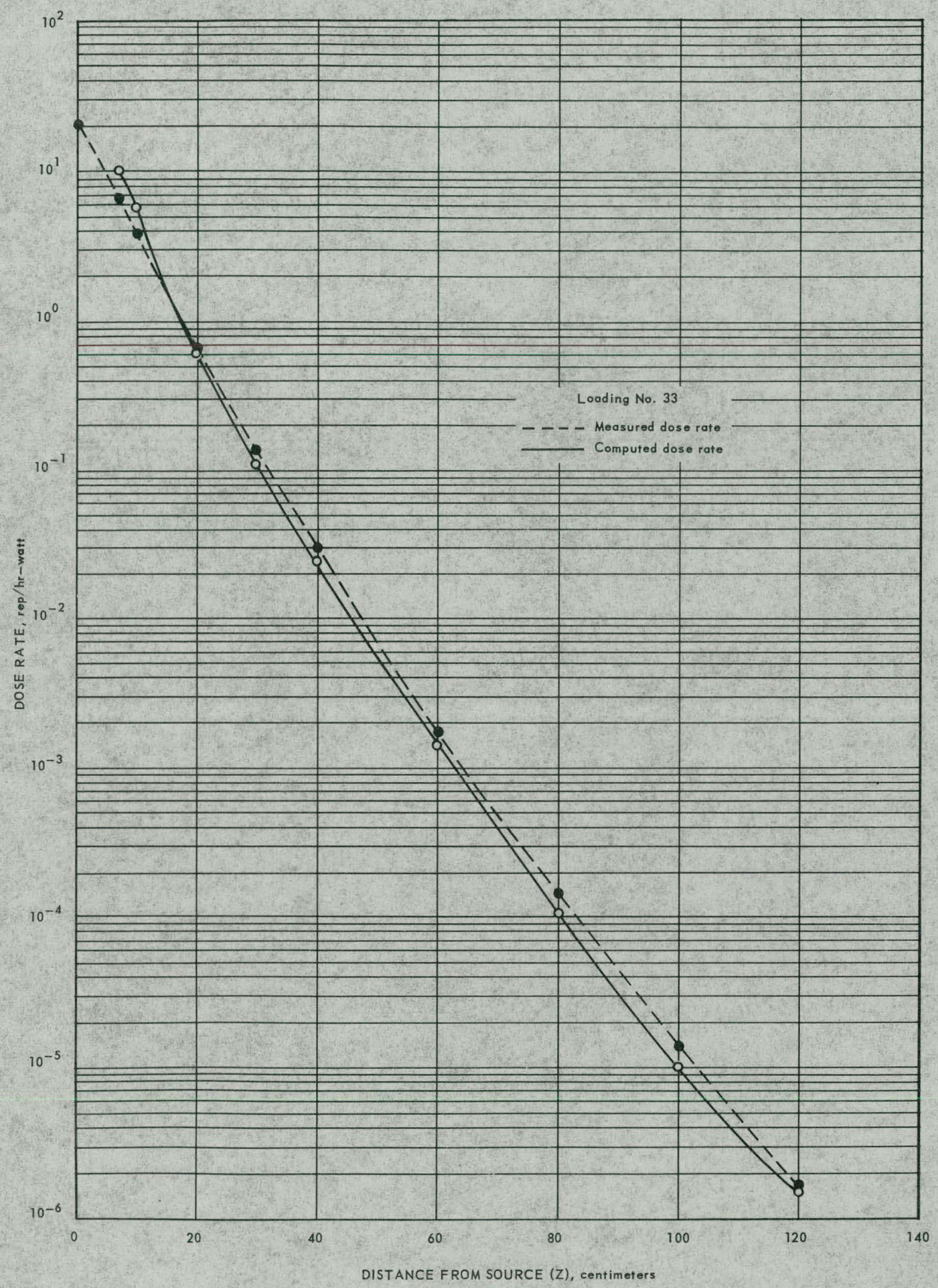

Fig. 7 - Comparison of measured and computed program 14-0 BSR centerline neutron dose rates in water 


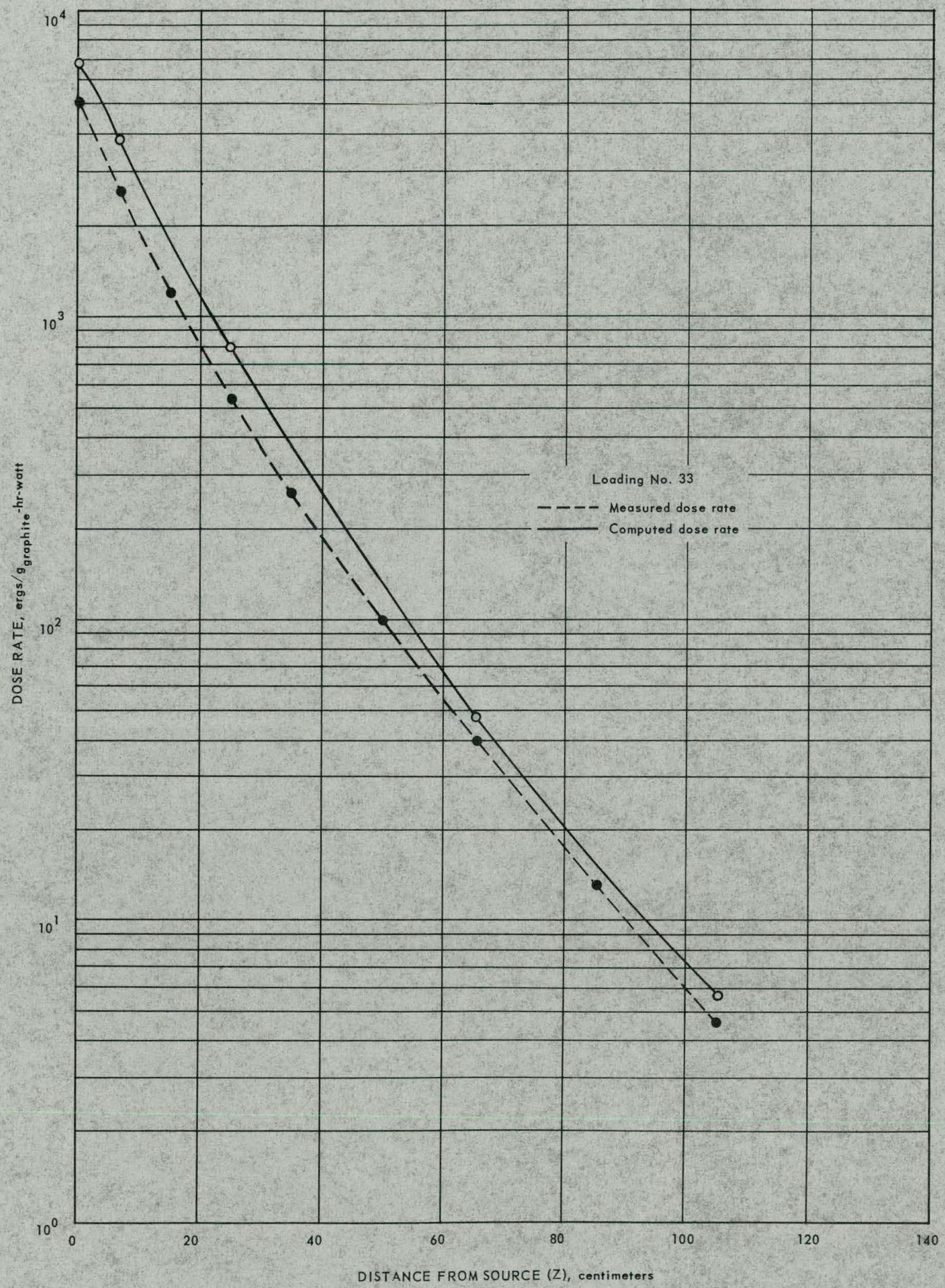

Fig. 8-Comparison of measured and computed program 04-2 BSR centerline gamma duse rates in water 


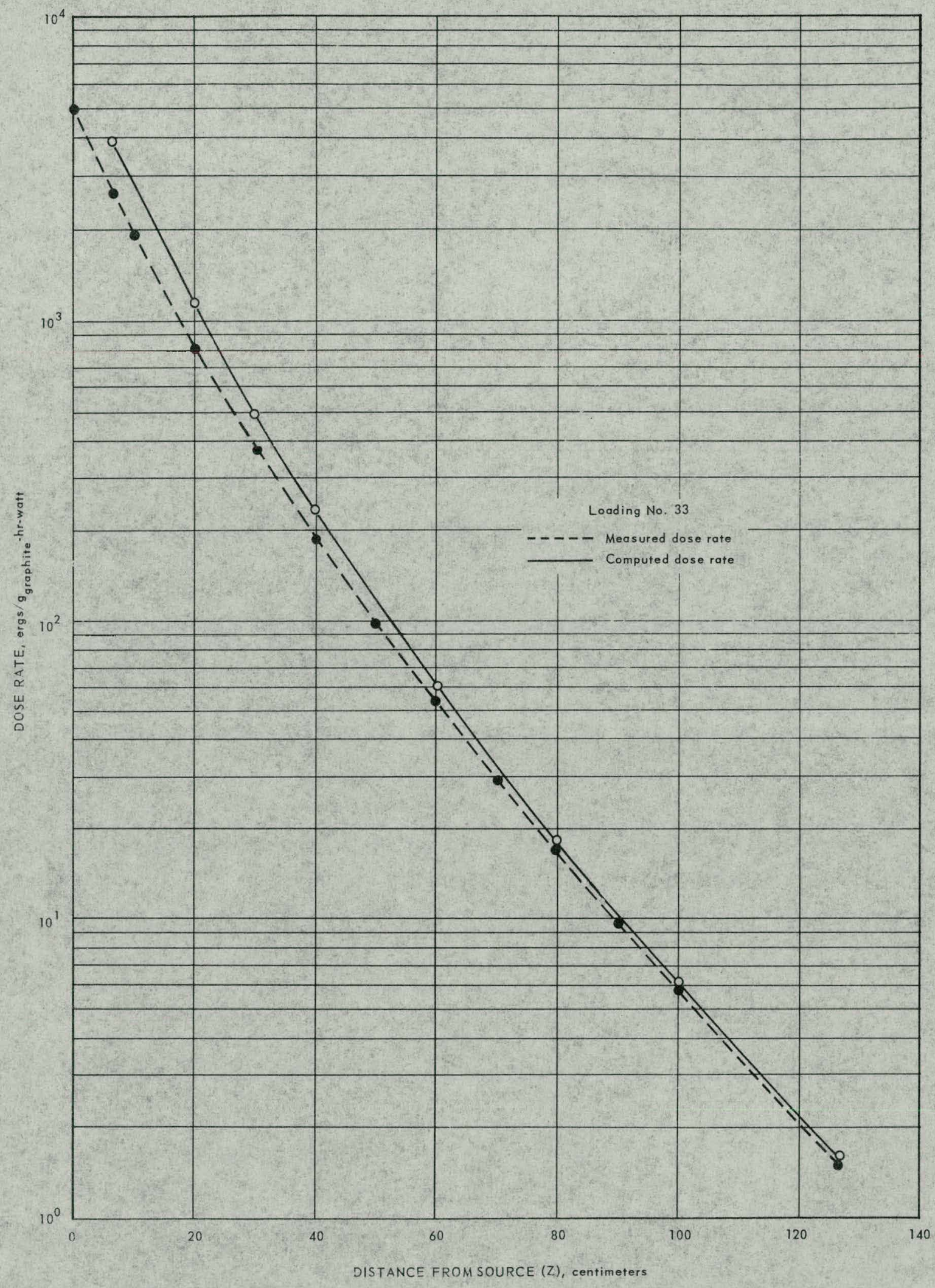

Fig. 9-Comparison of measured and computed program 04-1 BSR centerline gamma dose rates in water 


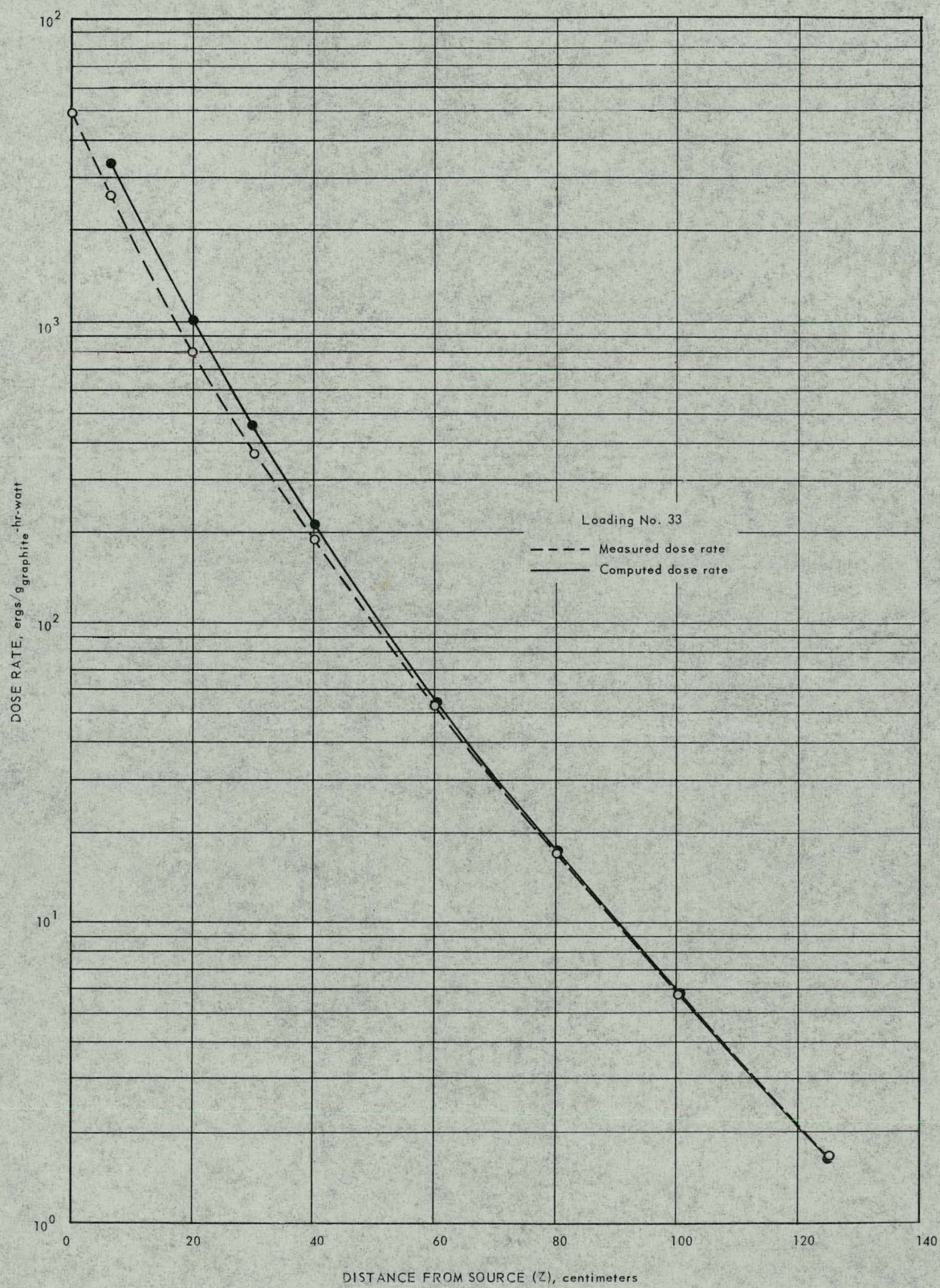

Fig. 10 - Comparison of measured and computed program 14-0 BSR centerline gamma dose rates in water 
THIS PAGE

WAS INTENTIONALLY

LEFT BLANK 
TABLE 1

POWER DENSITY AT SOURCE POINTS IN ONE-QUARTER CORE FOR PROGRAM 04-1

BSR Loading 33

\begin{tabular}{|c|c|c|c|c|c|c|c|}
\hline $\mathrm{X}, \mathrm{cm}$ & $\mathrm{Y}, \mathrm{cm}$ & $\mathrm{Z}, \mathrm{cm}$ & $\mathrm{p}$, watts $/ \mathrm{cm}^{3}$ & $\mathrm{X}, \mathrm{cm}$ & $\mathrm{Y}, \mathrm{cm}$ & $\mathrm{Z}, \mathrm{cm}$ & $\mathrm{p}$, watts $/ \mathrm{cm}^{3}$ \\
\hline 0 & 0 and & -23.127 & $1.13 \times 10^{-5}$ & 0 & 4. 05 and & -23.127 & $1.055 \times 10^{-5}$ \\
\hline 0 & & -15.418 & $1.13 \times 10^{-5}$ & 0 & & -15.418 & 1. $055 \times 10^{-5}$ \\
\hline 0 & & -15.418 & $9.017 \times 10^{-6}$ & 0 & & -15.418 & 1. $502 \times 10^{-5}$ \\
\hline 0 & & -7.709 & $9.017 \times 10^{-6}$ & 0 & & -7.709 & $1.502 \times 10^{-5}$ \\
\hline 0 & & -7.709 & $8.956 \times 10^{-6}$ & 0 & & -7.709 & $1.628 \times 10^{-5}$ \\
\hline 0 & & 0 & $8.956 \times 10^{-6}$ & 0 & & 0 & $1.628 \times 10^{-5}$ \\
\hline 0 & & 0 & $1.885 \times 10^{-5}$ & 0 & & 0 & 8. $722 \times 10^{-6}$ \\
\hline 0 & & 7. 709 & $1.885 \times 10^{-5}$ & 0 & & 7. 709 & 8. $722 \times 10^{-6}$ \\
\hline 0 & & 7. 709 & 1. $2904 \times 10^{-5}$ & 0 & & 7.709 & $1.268 \times 10^{-5}$ \\
\hline 0 & & 15.418 & $1.2904 \times 10^{-5}$ & 0 & & 15.418 & $1.268 \times 10^{-5}$ \\
\hline 0 & & 15.418 & 1. $208 \times 10^{-5}$ & 0 & & 15.418 & 1. $099 \times 10^{-5}$ \\
\hline 0 & & 23.127 & $1.208 \times 10^{-5}$ & 0 & & 23.127 & 1. $099 \times 10^{-5}$ \\
\hline 0 & & -23.127 & 0 & 5.08 & 0 and & -23.127 & $1.108 \times 10^{-5}$ \\
\hline 0 & & -15.418 & 0 & 5. 08 & 4.05 & -15.418 & 1. $108 \times 10^{-5}$ \\
\hline 0 & & -15.418 & $1.126 \times 10^{-5}$ & 5.08 & & -15.418 & 8. $834 \times 10^{-6}$ \\
\hline 0 & & -7.709 & $1.126 \times 10^{-5}$ & 5. 08 & & -7.709 & 8. $834 \times 10^{-6}$ \\
\hline 0 & & -7.709 & $1.42 \times 10^{-5}$ & 5.08 & & -7.709 & 8. $784 \times 10^{-6}$ \\
\hline 0 & & 0 & $1.42 \times 10^{-5}$ & 5.08 & & 0 & $8.784 \times 10^{-6}$ \\
\hline 0 & & 0 & $1.477 \times 10^{-5}$ & 5.08 & & 0 & 1. $843 \times 10^{-5}$ \\
\hline 0 & & 7.709 & $1.477 \times 10^{-5}$ & 5.08 & & 7. 709 & $1.843 \times 10^{-5}$ \\
\hline 0 & & 7. 709 & $1.217 \times 10^{-5}$ & 5.08 & & 7. 709 & $1.252 \times 10^{-5}$ \\
\hline 0 & & 15.418 & $1.217 \times 10^{-5}$ & 5.08 & & 15.418 & $1.252 \times 10^{-5}$ \\
\hline 0 & & 15.418 & 9.42 & 5.08 & & 5.418 & 1. $16 \times 10^{-5}$ \\
\hline 0 & & 23. 127 & $9.427 \times 10^{-6}$ & 5.08 & & 23.127 & $1.16 \times 10^{-5}$ \\
\hline 5.08 & $\overline{4.0}$ & 127 & $0^{-5}$ & & 12.15 & & 0 \\
\hline 5.08 & 12.15 & -15.418 & & & and & 118 & 0 \\
\hline 5.08 & & -15.418 & $1.471 \times 10^{-5}$ & 5.08 & 20.25 & -15.418 & $1.103 \times 10^{-5}$ \\
\hline 5.08 & & -7.709 & $1.471 \times 10^{-5}$ & 5.08 & & -7.709 & 1. $103 \times 10^{-5}$ \\
\hline 5.08 & & -7.709 & $1.595 \times 10^{-5}$ & 5.08 & & -7.709 & 1. $377 \times 10^{-5}$ \\
\hline 5.08 & & 0 & $1.595 \times 10^{-5}$ & 5.08 & & 0 & $1.377 \times 10^{-5}$ \\
\hline 5.08 & & 0 & $8.455 \times 10^{-6}$ & 5.08 & & 0 & $1.432 \times 10^{-5}$ \\
\hline 5.08 & & 7.709 & $8.455 \times 10^{-6}$ & 5.08 & & 7.709 & $1.432 \times 10^{-5}$ \\
\hline 5.08 & & 7.709 & 1.2 & 5.08 & & 7.709 & $\times 10^{-5}$ \\
\hline 5.08 & & 15.418 & $1.23 \times 10^{-5}$ & 5.08 & & 15.418 & $1.193 \times 10^{-5}$ \\
\hline 5.08 & & 15.418 & $1.055 \times 10^{-5}$ & 5.08 & & 15.418 & $9.238 \times 10^{-6}$ \\
\hline 5.08 & & 23.127 & $1.055 \times 10^{-5}$ & 5.08 & & 23. 127 & $9.238 \times 10^{-6}$ \\
\hline 10. & 0 & -2 & $0^{-5}$ & 6 & 4. 05 and & -2 & $10^{-6}$ \\
\hline 10.16 & 4.05 & & $\times 10^{-5}$ & & 12.15 & -1 & $8.657 \times 10^{-6}$ \\
\hline 10.16 & & -15 & $8.291 \times 10^{-6}$ & 10.16 & & -15.418 & 1. $367 \times 10^{-5}$ \\
\hline 10.16 & & -7.709 & $8.291 \times 10^{-6}$ & 10.16 & & -7.709 & 1. $367 \times 10^{-5}$ \\
\hline 10.16 & & -7.709 & $8.241 \times 10^{-6}$ & 10.16 & & -7.709 & $1.482 \times 10^{-5}$ \\
\hline 10.16 & & 0 & $8.241 \times 10^{-6}$ & 10.16 & & 0 & $1.482 \times 10^{-5}$ \\
\hline 10.16 & & 0 & $1.691 \times 10^{-5}$ & 10.16 & & 0 & $7.85 \times 10^{-6}$ \\
\hline 10.16 & & 7.709 & $1.691 \times 10^{-5}$ & 10.16 & & 7.709 & $7.85 \times 10^{-6}$ \\
\hline 10.16 & & 7. 709 & $1.161 \times 10^{-5}$ & 10.16 & & 7. 709 & 1. $142 \times 10^{-5}$ \\
\hline 10.16 & & 15.418 & $1.161 \times 10^{-5}$ & 10.16 & & 15.418 & 1. $142 \times 10^{-5}$ \\
\hline 10.16 & & 15.418 & $1.051 \times 10^{-5}$ & 10.16 & & 15.418 & $9.566 \times 10^{-6}$ \\
\hline 10.16 & & 23.127 & $1.051 \times 10^{.5}$ & 10.16 & & 23. 127 & $9.588 \times 10^{-6}$ \\
\hline
\end{tabular}


TABLE 1 (Cont.)

POWER DENSITY AT SOURCE POINTS IN ONE-QUARTER CORE FOR PROGRAM 04-1

BSR Loading 33

\begin{tabular}{|c|c|c|c|c|c|c|c|}
\hline $\mathrm{X}, \mathrm{cm}$ & $\mathrm{Y}, \mathrm{cm}$ & $\mathrm{Z}, \mathrm{cm}$ & $\mathrm{p}$, watts $/ \mathrm{cm}^{3}$ & $\mathrm{X}, \mathrm{cm}$ & $\mathrm{Y}, \mathrm{cm}$ & $\mathrm{Z}, \mathrm{cm}$ & $\mathrm{p}$, watts $/ \mathrm{cm}^{3}$ \\
\hline 10.16 & 12.15 & -23.127 & 0 & 15.24 & 0 and & -23.127 & $9.049 \times 10^{-6}$ \\
\hline 10.16 & and & -15.418 & 0 & 15.24 & 4. 05 & -15.418 & $9.049 \times 10^{-6}$ \\
\hline 10. 16 & 20.25 & -15.418 & $1.025 \times 10^{-5}$ & 15.24 & & -15.418 & $7.32 \times 10^{-6}$ \\
\hline 10.16 & & -7.709 & $1.025 \times 10^{-5}$ & 15.24 & & -7.709 & $7.32 \times 10^{-6}$ \\
\hline 10.16 & & -7.709 & $1.263 \times 10^{-5}$ & 15.24 & & -7.709 & $7.206 \times 10^{-6}$ \\
\hline 10.16 & & 0 & $1.263 \times 10^{-5}$ & 15.24 & & 0 & $7.206 \times 10^{-6}$ \\
\hline 10.16 & & 0 & $1.329 \times 10^{-5}$ & 15.24 & & $\mathbf{0}$ & 1. $477 \times 10^{-5}$ \\
\hline 10. 16 & & 7.700 & $1.329 \times 10^{-5}$ & 15.24 & & 7.709 & 1. $477 \times 10^{-5}$ \\
\hline 10. 16 & & 7.709 & $1.095 \times 10^{-5}$ & 15.24 & & 7.709 & 1. $017 \times 10^{-5}$ \\
\hline 10. 16 & & 15.418 & $1.095 \times 10^{-5}$ & 15. 24 & & 15.418 & $1.017 \times 10^{-5}$ \\
\hline 10.16 & & 15.418 & $8.481 \times 10^{-6}$ & 15.24 & & 15.418 & 9. $364 \times 10^{-6}$ \\
\hline 10.16 & & 23.127 & $8.481 \times 10^{-6}$ & 15.24 & $\downarrow$ & 23. 127 & $9.364 \times 10^{-6}$ \\
\hline 15.24 & 4. 05 and & -23.127 & $6.398 \times 10^{-6}$ & 15.24 & 12. 15 and & -23.127 & 0 \\
\hline 15.24 & $12.15^{\circ}$ & -15.418 & $6.398 \times 10^{-6}$ & 15.24 & 20.25 & -15.418 & 0 \\
\hline 15.24 & & -15.418 & $1.184 \times 10^{-5}$ & 15.24 & & -15.418 & $8.973 \times 10^{-6}$ \\
\hline 15.24 & & -7.709 & $1.184 \times 10^{-5}$ & 15.24 & & -7.709 & $8.973 \times 10^{-6}$ \\
\hline 15.24 & & -7.709 & $1.285 \times 10^{-5}$ & 15.24 & & -7.709 & 1. $113 \times 10^{-5}$ \\
\hline 15.24 & & 0 & $1.285 \times 10^{-5}$ & 15.24 & & $\mathbf{0}$ & 1. $113 \times 10^{-5}$ \\
\hline 15.24 & & 0 & $6.853 \times 10^{-6}$ & 15.24 & & 0 & 1. $153 \times 10^{-5}$ \\
\hline 15.24 & & 7. 709 & $6.853 \times 10^{-6}$ & 15.24 & & 7.709 & 1. $153 \times 10^{-5}$ \\
\hline 15.24 & & 7.709 & $1.011 \times 10^{-5}$ & 15.24 & & 7.709 & $9.389 \times 10^{-6}$ \\
\hline 15.24 & & 15. 418 & $1.011 \times 10^{-5}$ & 15.24 & & 15.418 & $9.389 \times 10^{-6}$ \\
\hline 15.24 & & 15.418 & $8.317 \times 10^{-6}$ & 15.24 & & 15.418 & $7.433 \times 10^{-6}$ \\
\hline 15.24 & & 23.127 & $8.317 \times 10^{-6}$ & 15.24 & & 23. 127 & 7. $433 \times 10^{-6}$ \\
\hline 20.32 & 0 and & -23.127 & 7. $686 \times 10^{-6}$ & 20.32 & 4. 05 and & -23.127 & 4. $644 \times 10^{-6}$ \\
\hline 20.32 & 4. 05 & -15.418 & $7.686 \times 10^{-6}$ & 20.32 & 12.15 & -15.418 & 4. $644 \times 10^{-6}$ \\
\hline 20.32 & & -15.418 & $6.31 \times 10^{-6}$ & 20.32 & & -15.418 & $1.006 \times 10^{-5}$ \\
\hline 20.32 & & -7.709 & $6.31 \times 10^{-6}$ & 20.32 & & -7.709 & $1.006 \times 10^{-5}$ \\
\hline 20,32 & & -7.709 & $5.995 \times 10^{-6}$ & 20.32 & & -7.709 & $1.042 \times 10^{-5}$ \\
\hline 20.32 & & 0 & $5.995 \times 10^{-6}$ & 20.32 & & 0 & $1.042 \times 10^{-5}$ \\
\hline 20.32 & & 0 & $1.225 \times 10^{-5}$ & 20.32 & & 0 & $5.49 \times 10^{-6}$ \\
\hline 20.32 & & 7.709 & $1.225 \times 10^{-5}$ & 20.32 & & 7.709 & $5.49 \times 10^{-6}$ \\
\hline 20.32 & & 7. 709 & $8.519 \times 10^{-6}$ & 20.32 & & 7.709 & $8.241 \times 10^{-6}$ \\
\hline 20.32 & & 15.418 & $8.519 \times 10^{-6}$ & 20.32 & & 15.418 & $8.241 \times 10^{-6}$ \\
\hline 20.32 & & 15.418 & $8.455 \times 10^{-6}$ & 20.32 & & 15.418 & 7. $143 \times 10^{-6}$ \\
\hline 20.32 & 1 & 23.127 & $8.455 \times 10^{-6}$ & 20.32 & - & 23.127 & 7. $143 \times 10^{-6}$ \\
\hline 20.32 & 12.15 & -23.127 & 0 & 25.4 & 0 and 4.05 & -23.127 & $6.891 \times 10^{-6}$ \\
\hline 20.32 & and & -15.418 & 0 & 25.4 & & -15.418 & $6.891 \times 10^{-6}$ \\
\hline 20.32 & 20.25 & -15.418 & $7.433 \times 10^{-6}$ & 25.4 & & -15.418 & $5.048 \times 10^{-6}$ \\
\hline 20.32 & & -7.709 & $7.433 \times 10^{-6}$ & 25.4 & & -7.709 & $5.048 \times 10^{-6}$ \\
\hline 20.32 & & -7.709 & $9.086 \times 10^{-6}$ & 25.4 & & -7.709 & $4.922 \times 10^{-6}$ \\
\hline 20.32 & & 0 & $9.086 \times 10^{-6}$ & 25.4 & & 0 & $4.922 \times 10^{-6}$ \\
\hline 20.32 & & 0 & $9.604 \times 10^{-6}$ & 25.4 & & 0 & $9.616 \times 10^{-6}$ \\
\hline 20.32 & & 7.709 & $9.604 \times 10^{-6}$ & 25.4 & & 7.709 & $9.616 \times 10^{-6}$ \\
\hline 20.32 & & 7.709 & $7.421 \times 10^{-6}$ & 25.4 & & 7.709 & $7.61 \times 10^{-6}$ \\
\hline 20.32 & & 15.418 & $7.421 \times 10^{-6}$ & 25.4 & & 15.418 & $7.61 \times 10^{-6}$ \\
\hline 20.32 & & 15.418 & $5.843 \times 10^{-6}$ & 25.4 & & 15.418 & $7.85 \times 10^{-6}$ \\
\hline 20.32 & & 23. 127 & $6.813 \times 10^{-6}$ & 25.1 & $\gamma$ & 23.127 & $7.85 \times 10^{-6}$ \\
\hline
\end{tabular}


TABLE 1 (Cont.)

POWER DENSITY AT SOURCE POINTS IN ONE-QUARTER CORE FOR PROGRAM 04-1

BSR Loading 33

\begin{tabular}{|c|c|c|c|c|c|c|c|}
\hline $\mathrm{X}, \mathrm{cm}$ & $\mathrm{n} \mathrm{Y}, \mathrm{cm}$ & $\mathrm{Z}, \mathrm{cm}$ & $\mathrm{p}$, watts $/ \mathrm{cm}^{3}$ & $\mathrm{X}, \mathrm{cm}$ & $\mathrm{Y}, \mathrm{cm}$ & $\mathrm{Z}, \mathrm{cm}$ & $\mathrm{p}$, watts $/ \mathrm{cm}^{3}$ \\
\hline 25.4 & 4. 05 and & -23.127 & $3.483 \times 10^{-6}$ & 25.4 & 12. 15 and & -23.127 & 0 \\
\hline 25.4 & 12.15 & -15.418 & $3.483 \times 10^{-6}$ & 25.4 & 20.25 & -15.418 & 0 \\
\hline 25.4 & & -15.418 & $9.011 \times 10^{-6}$ & 25.4 & & -15.418 & $6.31 \times 10^{-6}$ \\
\hline 25.4 & & -7.709 & $9.011 \times 10^{-6}$ & 25.4 & & -7.709 & $6.31 \times 10^{-6}$ \\
\hline 25.4 & & -7.709 & $8.468 \times 10^{-6}$ & 25.4 & & -7.709 & 7. $383 \times 10^{-6}$ \\
\hline 25.4 & & 0 & $8.468 \times 10^{-6}$ & 25.4 & & 0 & 7. $383 \times 10^{-6}$ \\
\hline 25.4 & & 0 & $4.442 \times 10^{-6}$ & 25.4 & & 0 & $7.383 \times 10^{-6}$ \\
\hline 25.4 & & 7.709 & 4. $442 \times 10^{-6}$ & 25.4 & & 7.709 & $7.383 \times 10^{-6}$ \\
\hline 25.4 & & 7.709 & $6.348 \times 10^{-6}$ & 25.4 & & 7.709 & $5.843 \times 10^{-6}$ \\
\hline 25.4 & & 15.418 & $6.348 \times 10^{-6}$ & 25.4 & & 15.418 & $5.843 \times 10^{-6}$ \\
\hline 25.4 & & 15.418 & $6.373 \times 10^{-6}$ & 25.4 & & 15.418 & 4. $72 \times 10^{-6}$ \\
\hline 25.4 & & 23. 127 & $6.373 \times 10^{-6}$ & 25.4 & & 23.127 & $4.72 \times 10^{-6}$ \\
\hline 30.48 & 0 and & -23.127 & $7.092 \times 10^{-6}$ & 30.48 & 4.05 and & -23.127 & $3.508 \times 10^{-6}$ \\
\hline 30.48 & 4. 05 & -15.418 & $7.092 \times 10^{-6}$ & 30.48 & 12.15 & -15.418 & $3.508 \times 10^{-6}$ \\
\hline 30.48 & & -15.418 & $5.061 \times 10^{-6}$ & 30.48 & & -15.418 & $9.301 \times 10^{-6}$ \\
\hline 30.48 & & -7.709 & $5.061 \times 10^{-6}$ & 30.48 & & -7.709 & $9.301 \times 10^{-6}$ \\
\hline 30.48 & & -7.709 & $4.922 \times 10^{-6}$ & 30.48 & & -7.709 & $8.607 \times 10^{-6}$ \\
\hline 30.48 & & 0 & 4. $922 \times 10^{-6}$ & 30.48 & & 0 & $8.607 \times 10^{-6}$ \\
\hline 30.48 & & 0 & $9.591 \times 10^{-6}$ & 30.48 & & 0 & 4. $417 \times 10^{-6}$ \\
\hline 30.48 & & 7.709 & $9.591 \times 10^{-6}$ & 30.48 & & 7.709 & 4. $417 \times 10^{-6}$ \\
\hline 30.48 & & 7.709 & $7.774 \times 10^{-6}$ & 30.48 & & 7.709 & $6.26 \times 10^{-6}$ \\
\hline 30.48 & & 15.418 & $7.774 \times 10^{-6}$ & 30.48 & & 15.418 & $6.26 \times 10^{-6}$ \\
\hline 30.48 & & 15.418 & $8.089 \times 10^{-6}$ & 30.48 & & 15.418 & $6.575 \times 10^{-6}$ \\
\hline 30.48 & & 23.127 & $8.089 \times 10^{-6}$ & 30.48 & & 23.127 & $6.575 \times 10^{-6}$ \\
\hline 30.48 & 12.15 & -23.127 & 0 & & & & \\
\hline 30.48 & and & -15.418 & 0 & & & & \\
\hline 30.48 & 20.25 & -15.418 & $5.995 \times 10^{-6}$ & & & & \\
\hline 30.48 & & -7.709 & $5.995 \times 10^{-6}$ & & & & \\
\hline 30.48 & & -7.709 & $7.08 \times 10^{-6}$ & & & & \\
\hline 30.48 & & 0 & $7.08 \times 10^{-6}$ & & & & \\
\hline 30.48 & & 0 & $6.79 \times 10^{-6}$ & & & & \\
\hline 30.48 & & 7.709 & $6.79 \times 10^{-6}$ & & & & \\
\hline 30.48 & & 7.709 & $5.376 \times 10^{-6}$ & & & & \\
\hline 30.48 & & 15.418 & $5.376 \times 10^{-6}$ & & & & \\
\hline 30.48 & 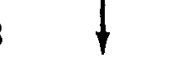 & 15.418 & $4.556 \times 10^{-6}$ & & & & \\
\hline
\end{tabular}


TABLE 2

SOURCE DESCRIPTION FOR PROGRAM 14-0

BSR Loading No. 33

\section{Axial Boundary Values}

Range $1 \mathrm{Z}=-30.48$ to $\mathrm{Z}=-22.352 \mathrm{~cm}$

Range $2 \mathrm{Z}=-22.352$ to $\mathrm{Z}=22.352 \mathrm{~cm}$

Range $3 \mathrm{Z}=22.352$ to $\mathrm{Z}=30.48 \mathrm{~cm}$

Type 1 - 9 lines

\begin{tabular}{|c|c|c|}
\hline Location: & $\mathrm{R}, \mathrm{cm}$ & $\phi$ \\
\hline & 16.2 & 3.1416 \\
\hline & 0 & 0 \\
\hline & 16. 2 & 0 \\
\hline & 17.94 & 3.5857 \\
\hline & 11. 18 & 3.9023 \\
\hline & 11. 18 & 5.5225 \\
\hline & 17. 94 & 5. 8391 \\
\hline & 17.42 & 4. 2287 \\
\hline & 17.42 & 5.1961 \\
\hline
\end{tabular}

Axial Power Distribution

Range 1

Range 2

Range 3

$\frac{\xi 2}{-26.42}$
0
26.42

$\frac{\xi 3}{5.773 \times 10^{-4}}$
$5.773 \times 10^{-4}$
$5.773 \times 10^{-4}$

$\frac{\xi 4}{-1.021 \times 10^{-4}}$

0.3865

0.07028

0.3865

Type 2 - 3 lines

Location:

\begin{tabular}{|c|c|}
\hline $\mathrm{R}, \mathrm{cm}$ & $\phi$ \\
\hline 15.42 & 1. 5708 \\
\hline 17.94 & 2.6975 \\
\hline 17.94 & 0.44415 \\
\hline
\end{tabular}

Axial Power Distribution

Range 1

$\begin{array}{lc}\frac{\xi 1}{0.3865} & \frac{\xi 2}{26.42} \\ 0.07028 & 0 \\ 0.3865 & 26.42\end{array}$

$\frac{\xi 3}{4.523 \times 10^{-4}}$

4. $523 \times 10^{-4}$
4. $523 \times 10^{-4}$

3. $769 \times 10^{-4}$

$-1.021 \times 10^{-4}$

Range 2

Range 3

0. 3865

Type 3 - 3 lines

\begin{tabular}{|c|c|c|}
\hline \multirow[t]{4}{*}{ Location: } & $\mathrm{R}, \mathrm{cm}$ & $\phi$ \\
\hline & 11.18 & 2.3809 \\
\hline & 7.709 & 1. 5708 \\
\hline & 11.18 & 0.76067 \\
\hline
\end{tabular}


TABLE 2 (Cont.)

SOURCE DESCRIPTION FOR PROGRAM 14-0

BSR Loading No. 33

\begin{tabular}{|c|c|c|c|c|}
\hline \multicolumn{5}{|c|}{ Axial Power Distribution } \\
\hline & $\xi 1$ & $\xi 2$ & $\xi 3$ & $\xi 4$ \\
\hline Range 1 & 0.3865 & -26.42 & $3.3 \times 10^{-4}$ & $-5.836 \times 10^{-5}$ \\
\hline Range 2 & 0.07028 & 0 & $3.3 \times 10^{-4}$ & $2.155 \times 10^{-4}$ \\
\hline Range 3 & 0.3865 & 26.42 & $3.3 \times 10^{-4}$ & $-5.836 \times 10^{-5}$ \\
\hline \multicolumn{5}{|c|}{ All Types } \\
\hline \multicolumn{5}{|c|}{ Radial Power Distribution } \\
\hline & $\xi 1$ & $\xi 2$ & $\xi 3$ & $\xi 4$ \\
\hline & 0 & 0 & 0 & 1 \\
\hline
\end{tabular}


TABLE 2 (Cont.)

SOURCE DESCRIPTION FOR PROGRAM 14-0

BSR Loading No. 33

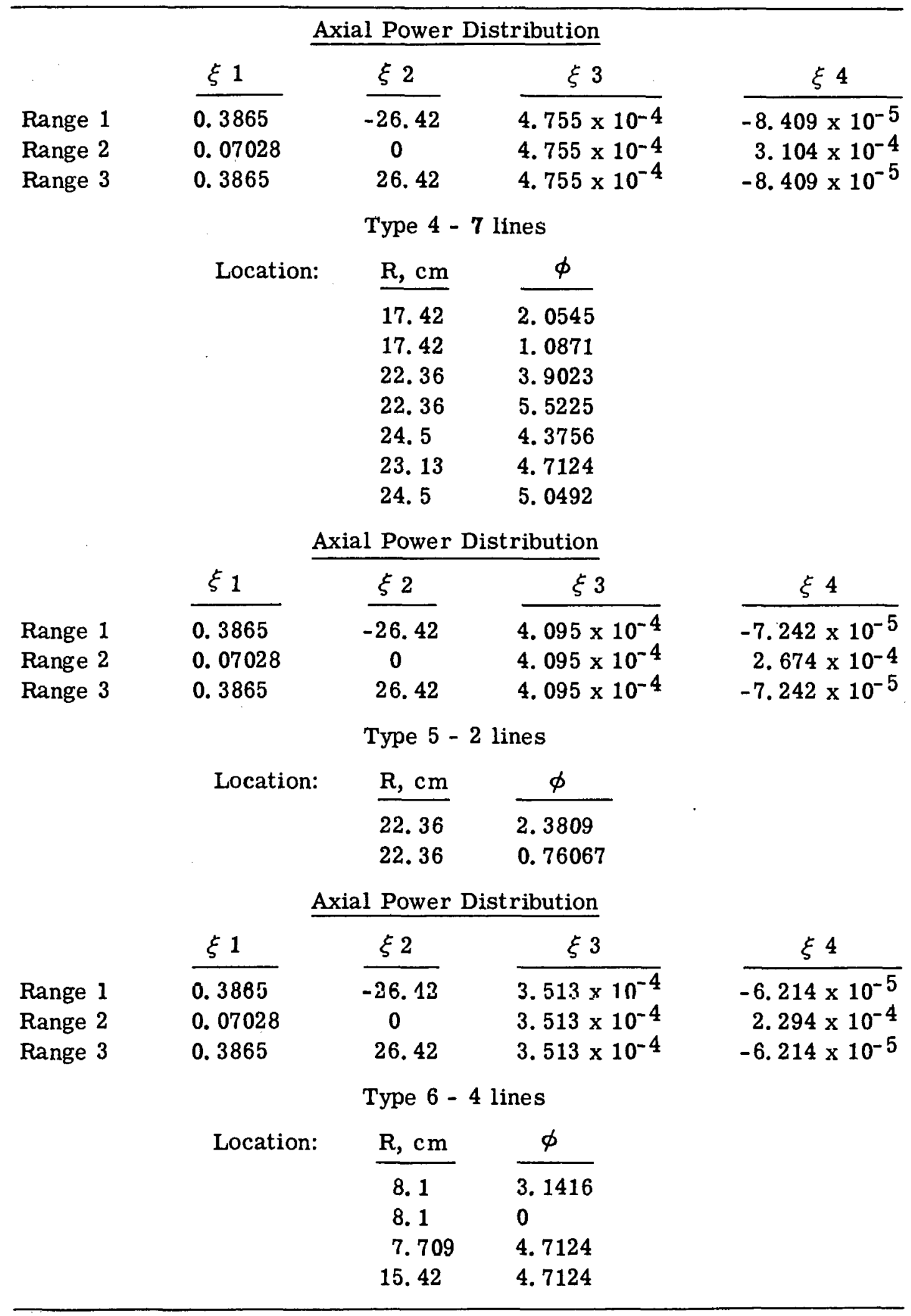


TABLE 3

GAMMA RAY SOURCE INTENSITY

\begin{tabular}{ll} 
E, Mev & B, Mev/watt-sec \\
\hline 0.375 & $9.505 \times 10^{10}$ \\
1 & $9.453 \times 10^{10}$ \\
1.5 & $7.528 \times 10^{10}$ \\
2 & $8.059 \times 10^{10}$ \\
2.5 & $4.167 \times 10^{10}$ \\
3 & $2.972 \times 10^{10}$ \\
3.625 & $2.853 \times 10^{10}$ \\
4.5 & $2.061 \times 10^{10}$ \\
5.5 & $9.33 \times 10^{9}$ \\
6.5 & $5.106 \times 10^{9}$ \\
7.5 & $7.385 \times 10^{9}$ \\
8.5 & $3.069 \times 10^{8}$ \\
9.5 & $5.594 \times 10^{7}$ \\
0.5 & $1.629 \times 10^{11}$ \\
1.5 & $1.697 \times 10^{11}$ \\
2.5 & $8.525 \times 10^{10}$ \\
3.5 & $4.014 \times 10^{10}$ \\
4.5 & $2.024 \times 10^{10}$ \\
5.5 & $1.159 \times 10^{10}$ \\
6.5 & $8.46 \times 10^{9}$ \\
7.5 & $8.59 \times 10^{9}$ \\
8.5 & $3.69 \times 10^{8}$ \\
9.5 & $1.36 \times 10^{8}$ \\
\hline
\end{tabular}

TABLE 4

DOSE BUILDUP FOR WATER ${ }^{a}$

13 Energy Intervals

\begin{tabular}{lllll}
\hline E, Mev & $\mathrm{B}_{0}$ & \multicolumn{1}{c}{$\mathrm{B}_{1}$} & \multicolumn{1}{c}{$\mathrm{B}_{2}$} & \multicolumn{1}{c}{$\mathrm{B}_{3}$} \\
\hline 0.375 & 1 & 1.119 & 0.6449 & 0.04602 \\
1 & 1 & 0.9396 & 0.193 & -0.002593 \\
1.5 & 1 & 0.915 & 0.09 & -0.00146 \\
2 & 1 & 0.812 & 0.0425 & -0.00098 \\
2.5 & 1 & 0.746 & 0.016 & -0.00049 \\
3 & 1 & 0.692 & 0.0081 & -0.00015 \\
3.625 & 1 & 0.618 & 0.0042 & -0.0004 \\
4.5 & 1 & 0.544 & -0.0007 & 0.00002 \\
5.5 & 1 & 0.487 & -0.005 & 0.00011 \\
6.5 & 1 & 0.438 & -0.0066 & 0.00013 \\
7.5 & 1 & 0.397 & -0.0072 & 0.00016 \\
8.5 & 1 & 0.36 & -0.0074 & 0.00018 \\
9.5 & 1 & 0.334 & -0.0075 & 0.0002
\end{tabular}

10 Energy Intervals

\begin{tabular}{lllll}
0.5 & 1 & 0.849 & 0.582 & 0.00988 \\
1.5 & 1 & 0.915 & 0.09 & -0.00146 \\
2.5 & 1 & 0.746 & 0.016 & -0.00049 \\
3.5 & 1 & 0.633 & 0.0048 & -0.00005 \\
4.5 & 1 & 0.544 & -0.0007 & 0.00002 \\
5.5 & 1 & 0.487 & -0.005 & 0.00011 \\
6.5 & 1 & 0.438 & -0.0066 & 0.00013 \\
7.5 & 1 & 0.397 & -0.0072 & 0.00016 \\
8.5 & 1 & 0.36 & -0.0074 & 0.00018 \\
9.5 & 1. & 0.334 & -0.0075 & 0.0002 \\
\hline
\end{tabular}

$a_{\text {Reference } 3 \text {. }}$ 
TABLE 5

GAMMA RAY LINEAR ABSORPTION CROSS SECTIONS ${ }^{2}$

\begin{tabular}{|c|c|c|c|}
\hline $\mathrm{E}, \mathrm{Mev}$ & $\sum{ }^{\mathrm{H}_{2} \mathrm{O}} \mathrm{cm}^{-1}$ & $\sum \stackrel{\mathrm{Al}}{\mathrm{cm}^{-1}}$ & $\sum \stackrel{\mathrm{U}}{\mathrm{cm}^{-1}}$ \\
\hline 0.375 & 0.109 & 0.258 & 5.8 \\
\hline 1 & 0.0706 & 0. 1658 & 1.416 \\
\hline 1.5 & 0.0576 & 0.135 & 1. 051 \\
\hline 2 & 0.0493 & 0.1164 & 0.9032 \\
\hline 2.5 & 0.0435 & 0.103 & 0.842 \\
\hline 3 & 0.0396 & 0.0953 & 0.8135 \\
\hline 3.625 & 0.0356 & 0.088 & 0.817 \\
\hline 4.5 & 0.0319 & 0.0788 & 0.823 \\
\hline 5.5 & 0.029 & 0,0734 & 0.86 \\
\hline 6.5 & 0.0268 & 0.0699 & 0.898 \\
\hline 7.5 & 0.0251 & 0.0677 & 0.935 \\
\hline 8.5 & 0.0235 & 0.0645 & 0.854 \\
\hline 9.5 & 0.0224 & 0.0629 & 0.972 \\
\hline 0.5 & 0.0962 & 0.232 & 3.366 \\
\hline 1.5 & 0.0565 & 0.135 & 1.047 \\
\hline 2.5 & 0.0435 & 0.103 & 0.842 \\
\hline 3.5 & 0.0361 & 0.0886 & 0.804 \\
\hline 4. 5 & 0.0319 & 0.0788 & 0.823 \\
\hline 5.5 & 0.029 & 0.0734 & 0.86 \\
\hline 6.5 & 0.0268 & 0.0699 & 0.898 \\
\hline 7.5 & 0.0251 & 0.0667 & 0.935 \\
\hline 8.5 & 0.0235 & 0.0645 & 0.954 \\
\hline 9.5 & 0.0224 & 0.0629 & 0.972 \\
\hline \multirow[t]{5}{*}{ ASSUMF } & \multicolumn{3}{|c|}{ D COMPOSITION OF THE BSR } \\
\hline & \multicolumn{2}{|c|}{ Volume Fractions } & \\
\hline & $\mathrm{H}_{2} \mathrm{O}$ & 0.583 & \\
\hline & Al & 0.415 & \\
\hline & U & 0.002 & \\
\hline
\end{tabular}

ASSUMED COMPOSITION OF THE BSR

\begin{tabular}{|c|c|c|c|}
\hline $\mathrm{E}, \mathrm{Mev}$ & $\sum{ }^{\mathrm{H}_{2} \mathrm{O}} \mathrm{cm}^{-1}$ & $\sum \stackrel{\mathrm{Al}}{\mathrm{cm}^{-1}}$ & $\sum \stackrel{\mathrm{U}}{\mathrm{cm}^{-1}}$ \\
\hline 0.375 & 0.109 & 0.258 & 5.8 \\
\hline 1 & 0.0706 & 0. 1658 & 1.416 \\
\hline 1.5 & 0.0576 & 0.135 & 1. 051 \\
\hline 2 & 0.0493 & 0.1164 & 0.9032 \\
\hline 2.5 & 0.0435 & 0.103 & 0.842 \\
\hline 3 & 0.0396 & 0.0953 & 0.8135 \\
\hline 3.625 & 0.0356 & 0.088 & 0.817 \\
\hline 4.5 & 0.0319 & 0.0788 & 0.823 \\
\hline 5.5 & 0.029 & 0,0734 & 0.86 \\
\hline 6.5 & 0.0268 & 0.0699 & 0.898 \\
\hline 7.5 & 0.0251 & 0.0677 & 0.935 \\
\hline 8.5 & 0.0235 & 0.0645 & 0.854 \\
\hline 9.5 & 0.0224 & 0.0629 & 0.972 \\
\hline 0.5 & 0.0962 & 0.232 & 3.366 \\
\hline 1.5 & 0.0565 & 0.135 & 1.047 \\
\hline 2.5 & 0.0435 & 0.103 & 0.842 \\
\hline 3.5 & 0.0361 & 0.0886 & 0.804 \\
\hline 4. 5 & 0.0319 & 0.0788 & 0.823 \\
\hline 5.5 & 0.029 & 0.0734 & 0.86 \\
\hline 6.5 & 0.0268 & 0.0699 & 0.898 \\
\hline 7.5 & 0.0251 & 0.0667 & 0.935 \\
\hline 8.5 & 0.0235 & 0.0645 & 0.954 \\
\hline 9.5 & 0.0224 & 0.0629 & 0.972 \\
\hline \multirow[t]{5}{*}{ ASSUMF } & \multicolumn{3}{|c|}{ D COMPOSITION OF THE BSR } \\
\hline & \multicolumn{2}{|c|}{ Volume Fractions } & \\
\hline & $\mathrm{H}_{2} \mathrm{O}$ & 0.583 & \\
\hline & Al & 0.415 & \\
\hline & U & 0.002 & \\
\hline
\end{tabular}

Volume Fractions

$a_{\text {Reference } 4 .}$

\begin{tabular}{|c|c|c|c|}
\hline $\mathrm{E}, \mathrm{Mev}$ & $\sum \stackrel{\mathrm{H}_{2} \mathrm{O}}{\mathrm{cm}^{-1}}$ & $\sum \mathrm{cm}^{\mathrm{Al}}$ & $\sum \mathrm{cm}^{\mathrm{U}}$ \\
\hline 0.375 & 0.109 & 0.258 & 5.8 \\
\hline 1 & 0.0706 & 0. 1658 & 1.416 \\
\hline 1.5 & 0.0576 & 0.135 & 1. 051 \\
\hline 2 & 0.0493 & 0.1164 & 0. 9032 \\
\hline 2.5 & 0.0435 & 0.103 & 0.842 \\
\hline 3 & 0.0396 & 0.0953 & 0.8135 \\
\hline 3.625 & 0.0356 & 0.088 & 0.817 \\
\hline 4.5 & 0.0319 & 0.0788 & 0.823 \\
\hline 5.5 & 0.029 & 0.0734 & 0.86 \\
\hline 6.5 & 0.0268 & 0.0699 & 0.898 \\
\hline 7.5 & 0.0251 & 0.0677 & 0.935 \\
\hline 8.5 & 0.0235 & 0.0645 & 0.854 \\
\hline 9.5 & 0.0224 & 0.0629 & 0.972 \\
\hline 0.5 & 0.0962 & 0.232 & 3.366 \\
\hline 1.5 & o. 0565 & 0.135 & 1.047 \\
\hline 2.5 & 0.0435 & 0.103 & 0.842 \\
\hline 3.5 & 0.0361 & 0.0886 & 0.804 \\
\hline 4.5 & 0.0319 & 0.0788 & 0.823 \\
\hline 5.5 & 0.029 & 0.0734 & 0.86 \\
\hline 6.5 & 0.0268 & 0.0699 & 0.898 \\
\hline 7.5 & 0.0251 & 0.0667 & 0.935 \\
\hline 8.5 & 0.0235 & 0.0645 & 0.954 \\
\hline 9.5 & 0.0224 & 0.0629 & 0.972 \\
\hline \multirow[t]{5}{*}{ ASSUMF } & \multicolumn{3}{|c|}{ D COMPOSITION OF THE BSR } \\
\hline & \multicolumn{2}{|c|}{ Volume Fractions } & \\
\hline & $\mathrm{H}_{2} \mathrm{O}$ & 0.583 & \\
\hline & Al & 0.415 & \\
\hline & U & 0.002 & \\
\hline
\end{tabular}




\section{TABLE 7}

THERMAL NEUTRON FLUX DISTRIBUTION

USED TO DESCRIBE THE SECONDARY GAMMA SOURCE

\begin{tabular}{|c|c|c|}
\hline \multicolumn{3}{|c|}{ First Axial Distribution } \\
\hline $\begin{array}{l}\mathrm{Z}=0 \text { to } 5 \\
\mathrm{Z}=5 \text { to } 30 \\
\mathrm{Z}=30 \text { to } 60 \\
\mathrm{Z}=60 \text { to } 100\end{array}$ & $\begin{array}{l}P_{1}(Z)=1.127 \times 10^{7} \mathrm{cos} \\
P_{2}(Z)=3.391 \times 10^{7} \mathrm{exI} \\
P_{3}(Z)=8.712 \times 10^{6} \mathrm{exI} \\
P_{4}(Z)=5 \times 10^{2}\end{array}$ & $\begin{array}{l}s-0.31416(Z-2.5)+3.03 \times 10^{6} \\
p-0.2061 z \\
p-0.16276 z \\
p-0.12749(Z-60)\end{array}$ \\
\hline \multicolumn{3}{|l|}{$\mathrm{r}, \mathrm{cm}$} \\
\hline $\begin{array}{l}r=0 \text { to } 5.08 \\
r=5.08 \text { to } 22.86 \\
r=22.86 \text { to } 50.8 \\
r=50.8 \text { to } 60.96\end{array}$ & 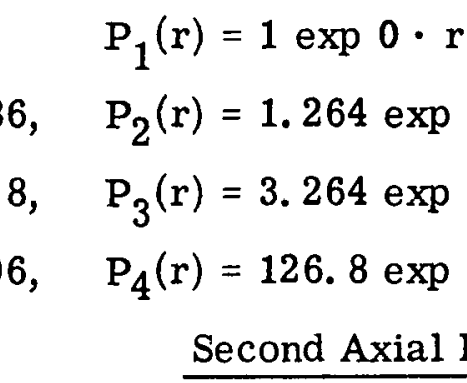 & $\begin{array}{l}-0.04617 \mathrm{r} \\
-0.08766 \mathrm{r} \\
-0.1597 \mathrm{r} \\
\text { Distribution }\end{array}$ \\
\hline \multicolumn{3}{|l|}{$\mathrm{Z}, \mathrm{cm}$} \\
\hline $\begin{array}{l}Z=100 \text { to } 170 \\
Z=170 \text { to } 200 \\
Z=200 \text { to } 250 \\
Z=250 \text { to } 400\end{array}$ & $\begin{array}{l}P_{1}(Z)=2.826 \\
P_{2}(Z)=1.541 \times 10^{-3} \\
P_{3}(Z)=1.902 \times 10^{-4} \\
P_{4}(Z)=2.5177 \times 10^{-5}\end{array}$ & $\begin{array}{l}\exp -0.10738(Z-100) \\
\exp -0.070642(Z-170) \\
\exp -0.039616(Z-200) \\
\exp -0.029793(Z-250)\end{array}$ \\
\hline
\end{tabular}

a The radial distribution is the same in both cases. 


\section{THIS PAGE}

\section{WAS INTENTIONALLY \\ LEFT BLANK}




\section{References}

1. "Attenuation in Water of Radiation from the Bulk Shielding Reactor; Measurement of Gamma Ray Dose Rate, Fast Neutron Dose Rate, and Thermal Neutron Flux," prepared by the staff of the Bulk Shielding Reactor, Oak Ridge National Laboratory, ORNL-2518.

2. Johnson, E. B., "Power Calibration for BSR Loading 33," CF 57-11-30, November 28, 1957.

3. Goldstein, Herbert; Wilkins, J. Emest, Jr., "Calculations of the Penetration of Gamma Rays," NYO-3075, June 30, 1954.

4. Grodstein, Gladys White, "X-Ray Attenuation Coefficients from $10 \mathrm{Kev}$ to $100 \mathrm{Mev}, " \mathrm{NBS}$ Circular 583, April 30, 1957.

5. Moteff, John, "Miscellaneous Data for Shielding Calculations," General Electric Company, Aircraft Nuclear Propulsion Department, APEX-176, Decemher 1, 1.954.

6. Capo, M. A.; Edwards, W. E.; Loechler, J. J.; and Paine, K. A.; "Shielding Computer Program 04-4, Reactor Shield Analysis," General Electric Company, Aircraft Nuclear Propulsion Department, XDC 59-7-150, July 22, 1959. 